continued steadily until in the summer of 1903-4 an Argentine vessel appeared to bring him back to civilisation. The Antarctic had found the ice conditions of the previous year so bad that a party was landed to attempt to reach Snow Hill by sledging over the coastal ice, while the vessel returned northward in the hope of getting in towards the land farther east. The Weddell Sea proved inexorable and the ship was crushed and sank. Larsen and his crew wintered in a hut, Gunnar Andersson and his land-party in another, and by the most dramatic coincidence in the history of exploration, both parties arrived at Snow Hill just in time to return as a united expediwith Capt. Irizar in the Uruguay.

On his return to Europe, Nordenskjöld was appointed professor of geography in the University of Göteborg, where he continued to occupy himself in preparing the full report of the results of his expedition, the publication of which was facilitated by a grant from the Swedish government. The Antarctic gives no rest to a man who has once come within the field of its attraction, and Nordenskjöld, like Scott and Shackleton, set his heart on a second and greater effort to get at the baffling problems of south polar geography, glaciology, and geology. By 1913 he had worked out, in conjunction with Admiral Palander, a scheme for an Anglo-Swedish expedition, and obtained promises of support from his own government and from influential authorities in Great Britain. The outbreak of war in 1914 put an end to the preparations, and he never saw the Antarctic again. In 1909 he had visited West Greenland, and since the War he made frequent visits to Spitsbergen and Iceland, continuing his earlier studies in Arctic geology. In 1920 he revisited Patagonia with a party of Swedish geologists, following the discovery of remarkable fossil reptiles.

During his tenure of the professorship at Göteborg, Nordenskjöld had always inspired his students with the spirit of research and maintained the high traditions of Swedish explorers and students of Nature. He was modest and unobtrusive in his manner, but insistent and persevering in the promotion of exploration and research. As a leader he was less a commander than a trusted comrade and a constant friend. An enthusiast in the search for knowledge, he was indifferent to the spectacular publicity which gratifies small-minded ambition. He always maintained the happiest relations with the geographers and polar explorers of other countries, and he will be greatly missed by many friends in all parts of the world, whose sympathy goes out to his widow and children.

Hugh Robert MmL.

\section{Dr. J. A. Thomson.}

Dr. James Allan Thomson, who passed away on May 6, was at the time of his death director of the Dominion Museum in Wellington, New Zealand, and also president of the New Zealand Institute. Notwithstanding ill - health, he had a very distinguished career. He was the first New Zealand Rhodes Scholar, and went to St. John's
College, Oxford, in 1906, where he was awarded the Burdett-Coutts Scholarship, and later he was appointed to a lectureship in geology at St. John's.

Leaving Oxford in 1908, Thomson worked on the geology of the Western Australian goldfields, and published several papers relating to them. $\mathrm{He}$ was chosen senior geologist for the second Scott Expedition in 1910, and went to Sydney to work with Sir Edgeworth David with the view of preparing himself for his work. Unfortunately, at this point in his career, the first signs of the disease to which he ultimately succumbed began to show, and, greatly to his own disappointment, and that of others, he was not allowed to go with the expedition.

Returning to New Zealand, Thomson joined the Geological Survey as palæontologist, a position which he held until 1914, when he was appointed to succeed the late Mr. A. A. Hamilton as director of the Dominion Museum, and in spite of failing health he continued to occupy this position until the end. Though repeatedly forced to lay aside his work and battle with disease, his scientific activities never ceased for long and his interest in scientific matters was never dulled. He published many papers on geological subjects, and during the last six years of his life he was busily occupied on a monograph on the brachiopods, a work which he lived just long enough to finish and to see in print.

For his geological work, Thomson was awarded the Hutton Medal of the New Zealand Institute, and last January was elected president of the Institute; he was also one of its original fellows. His death removes a scientific worker of the highest ideals and a man of exceptionally attractive personality ; in the face of much physical weakness he maintained an unconquerable cheerfulness. $\mathrm{He}$ died of tuberculosis at the early age of fortyseven years.

C. C. F.

Prof. Johannes Gadamer, Director of the Pharmaceutical-Chemical Institute in the University of Marburg, died on April 15 at the age of sixty-one years. A native of Waldenburg, in Silesia, he was appointed professor of pharmaceutical chemistry at the University of Breslau in 1902, and in 1919 he succeeded the late Prof. Ernst Schmidt at Marburg. Gadamer worked upon many alkaloids and glucosides. He also edited the Archiv der Pharmazie and published a "Lehrbuch der chemischen Toxikologie." After the death of Prof. E. Schmidt, Gadamer undertook the completion of his book, "Ausführliches Lehrbuch der pharmazeutischen Chemie."

Prof. G. Schultz, Director of the Chemical Technical Laboratory in the Technische Hochschule at Munich, died at the end of April, aged seventy-six years. A native of Finkenstein, in West Prussia, Schultz spent several years in the Berlin laboratories of the aniline dye factories, becoming later factory director at Basel. In 1896 he was appointed to the chair of chemical technology in Munich. He was the author of wellknown standard works, including "Die Chemie des Steinkohlenteers" and "Farbstofftabellen."

No. 3061, VoL. 121] 